\title{
Response Same Explant of Turi (Sesbania Grandiflora) in Shoot Induction Medium
}

\author{
Mardhiyetti", Zulfadly Syarif* Novirman Jamarun", Irfan Suliansyah* $^{*}$ \\ " Department of Husbandry, Andalas University, Indonesia \\ E-mail:mardhiyetti@ymail.com
}

*Department of Agriculture, Andalas University, Indonesia

\begin{abstract}
Cotyledon, leaf, root and hipokotyl explants of Sesbania grandiflora were excised from germinated seedlings and cultured on Murashige \& Skoog's basal medium supplemented with various combinations of cytokinin and auxin. Both cytokinin and auksin were required for induction of shoot. Medium of shoots induction has observed on MS medium supplement with BAP $1 \mathrm{mg} / \mathrm{l}$ and NAA $0.08 \mathrm{mg} / \mathrm{l}$. On this medium, $66.7 \%$ cultures responded with an average number of 1.7 shoots per explant cotiledon. However, the average shoot length was limited to 0.7. whereas shoots induction obtained on MS medium with addition $1 \mathrm{mg} / \mathrm{l}$ BAP and 0.08 mg/l NAA average shoot length $0.5 \mathrm{~cm} .50 \%$ cultur responded with an average number of 1 shoots per explant.
\end{abstract}

Keywords - Sesbania grandiflora, Shoots induction, BAP, NAA.

\section{INTRODUCTION}

Sesbania grandiflora belongs to the subfamily of papilionoideae of the leguminosae and is placed in the botanical tribe robinieae. Turi (Sesbania grandiflora) is a fast-growing tree, leaves are regular and rounded and the flowers white and red in color according to its species. The fruits are look like flat, long and thin green beans. The tree thrives under full exposure to sunshine and is extremely frost sensitive.

It is a small soft wooded tree up-to 3-8m, leaves $15-30$ cm long; leaflets 10-20 pairs or more and an odd one. Its oblong is $1.5-3.5 \mathrm{~cm}$ long variety red, $7.5-10 \mathrm{~cm}$ long in lax, 2-4 flower racemes, calyx campanulate, shallowly 2-lipped. Pods slender is falcate or straigh, $30-45 \mathrm{~cm}$ long, suture is thick, Seeds ca. 30, to 8mm [5].

Sesbania grandiflora is commonly managed for fodder production purposes as an parennial crop, because of its nitrogen fixing potential due nodulation by Rhizobium. It is also planted as as a cover crop or green manure during the summer season. In the process of growing cover crops involves the soil incorporation of Sesbania while green or soon after flowering, for the purpose of soil improvement.

It contain arginine, cysteine, histidine, isolcucine, phenylalanine, tryptophan, valine, threonine, alanine, aspargine, aspartic acid, oleanolic acid, galactose, Rhamnose $\&$ glucuronic acid.
Sesbania grandiflora is the tropical multipurpose luguminous tree [1] but not much information is revealed from these crops, such as cut-and plant responses to fertilization response. Eastern Indonesia cuts regularly (5 times a year) $100 \%$ dead [ 3].

[11] the intent of clonal propagation is to reproduce plants of desirable qualities uniformly and in quantity. That reproduction by tissuing culture is faster than by traditional nursery methods is generally acknowledged [4]. Regeneration of complete plants through tissuing culture has made it possible to introduce foreign genes in to plant cells and recover transgenic plants. Regeneration of shoots from meristem explants after agrobacterium infection is a simple and relatively efficient method for transformation in a number species like, Vigna mungo [9], Lotus japonicas [6], Acacia mangium [12], Glycin max [7] and L. leucocephala.

\section{MAterial AND MEthodS}

\section{A. Seed Germination and Explant Isolation}

Seed of Sesbania grandiflora were surface sterilized for 101 in concentrated bayclen $20 \%$, alkohol $70 \%$ and rinsed tree times with sterile distilled water.Additionally, seeds were immersed in sterile water for 1 day to promote imbibition. They were finally germinated in culture flasks containing ms medium, and then incubated for 2 week at 25o C. 
After seed imbibition, were used as the source of explants. The explants consistent of transfersal half $(0.4-0.6 \mathrm{~cm}$ in lenght) of a cotyledonary, epicotyl, hipocotyl, leaf and root. After isolation from seedlings, the explants were then transferred to induction medium.

\section{B. Culture Media and In vitro Growth Conditions of the Explants}

Salt and vitamins of MS were used as a basal medium. Sucrose $30 \mathrm{~g} / 1$, agar $8 \mathrm{~g} / \mathrm{l}$ and the growth regulator (BAP, NAA) were added before autoclaving. All the media were adjusted to $\mathrm{pH} 5.8$ with $\mathrm{KOH}$ or $\mathrm{HCl}$ then autoclaved at 121 o $\mathrm{C}$ for $15 \mathrm{~min}$. All the explant cultures were incubated at $25+20 \mathrm{C}$ by cool-white-fluorescent light at an irradiance of $30 \mathrm{mmol} \mathrm{S}-1 \mathrm{M}-2$.

\section{Invitro Induction of Shoot.}

Cotyledonary, hipocotyl, epicotyl, leaf and root were used as an explants source and the culture in inisiation medium consisted of murashige and skoog media ( MS), woody plant medium (WPM) and Gamborg medium (B5). For each treatment five explants on flasks were used and each experiment was repeated ten times. Explants were grown in inisiation media for 3 weeksThe best medium in initiation will be used on shoot induction. Explants were transferred into shoot induction medium supplemented with different concentration of NAA (0.00 dan 0.08) ppm and BAP $(0.00$, $1.00,2.00) \mathrm{ppm}$. For each treatment, ten explants were used and each experiment was repeated three times

\section{RESULTS AND DISCUSSION}

After doing the research by using same explant, it was found that cotiledon explant was the best for shoot induction. By treating 3\% sucrose supplemented with the same concentration by NAA and BAP. It was shown that cotyledonary shootled, while other explants; hipokotyll, leaf, root did not respon for growing. For more clear illustration, it can seen in the following fig 1.
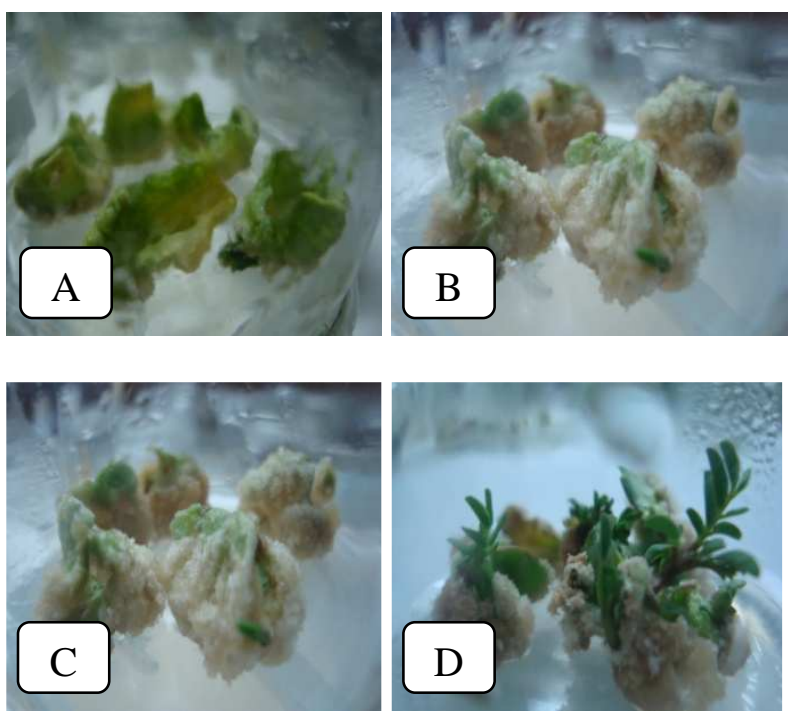

Fig. 1 Shoot induction from cotyledon (A-D)

Respon of BAP with NAA for shoot induction using cotyledonary as explants (Table 1). Formation on cotyledonary explant was taken from seed germanation. The
Cotyledonary explants cultured on MS medium supplemented with BAP $2 \mathrm{mg} / \mathrm{l}$ and NAA $0.08 \mathrm{mg} / \mathrm{l}$ gave rise to luxuriantly growing shoot .

TABLE I

RESPON OF EXPLANTS ON SHOOT INDUCTION

\begin{tabular}{|l|l|l|}
\hline NO & Explants & Explants Respon \\
\hline 1 & Cotyledonary & Shootled \\
\hline $\mathbf{2}$ & Hipocotyl & No shootled \\
\hline $\mathbf{3}$ & Leaf & No shootled \\
\hline $\mathbf{4}$ & Root & No shootled \\
\hline
\end{tabular}

Effect combination BAP and NAA for shoot induction of cotyledon explants can see in table 2. Shoot induction in MS medium supplemented by different NAA and BAP, show different respon for same explants.

TABLE II

EFFECT OF COMBINATION BAP AND NAA FOR SHOOT INDUCTION OF COTYLEDON EXPLANT OF SESBANIA GRANDIFLORA

\begin{tabular}{|c|c|c|c|c|}
\hline \multicolumn{2}{|c|}{$\begin{array}{l}\text { Plant growth } \\
\text { regulator }(\mathrm{mg} / \mathrm{l})\end{array}$} & $\begin{array}{l}\% \\
\text { shootled }\end{array}$ & $\begin{array}{l}\text { Number } \\
\text { of } \\
\text { shootled }\end{array}$ & $\begin{array}{l}\text { Average } \\
\text { shoot lengh } \\
\text { (cm) }\end{array}$ \\
\hline BAP & NAA & & & \\
\hline 0.00 & 0.00 & 0.0 & 0.0 & 0.0 \\
\hline 1.00 & 0.08 & 66.7 & 1.7 & 2.1 \\
\hline 2.00 & 0.08 & 71.7 & 5.3 & 0.7 \\
\hline
\end{tabular}

Shoot formation on kotyledon explants taken from seed germanation. The kotyledon explants cultured on $\mathrm{ms}$ medium supplemented with BAP $2 \mathrm{mg} / \mathrm{l}$ and NAA $0.08 \mathrm{mg} / \mathrm{l}$ gave rise to luxuriantly growing shoot.

The condition and medium provided were optimized for encouraging shoot proliferation. Friable organogenic shoot developed directly from kotyledon explants were periodically subcultured on the same medium supplemented but the average shoot length was limited to $0.7 \%$ compared BAP $1 \mathrm{ppm}$ and NAA $0.08 \mathrm{ppm}$ the average shoot length was $2.1 \%$. [2] Cotiledonary nodes are more responsive to multiple shoot induction compared to other nodes of other seedlings (Table 2). More 50\% determine of shootled and rooting in 0.2 ppm NAA. shown in Fig. 2. 


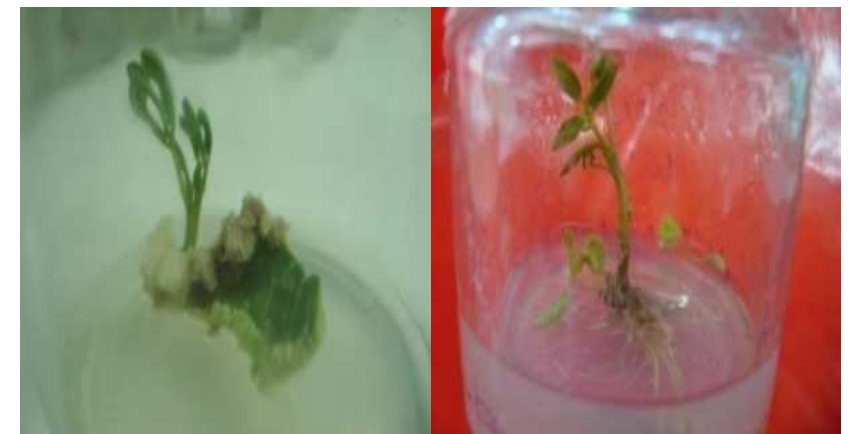

Fig.2 Shoot induction from kotyledon on MS medium added with BAP and NAA (A), and induction of root In Vitro for $0,2 \mathrm{ppm}$ NAA.

\section{CONCLUSIONS}

Shoot induction were induced from cotyledonary by used BAP . Though BA (BAP) (2.22-8.89 $\mathrm{mM})$ has been commonly used for induction of multiple shoots and direct shoot organogenesis studies in legumes (Prakash et al ., 1994; Saafi and Borthakur, 2002). (Shaik et al.,2009) Multiple shoot induction in cotyledonary nodes of Leucaena leucocephala suplemented with thidiazuron (TDZ ) or BA. An efficient medium for shoot induction through direct organogenesis of Sesbania grandiflora has been standardized. The regenerated plants were transplanted to rooting medium succesfully and were similar to the parental plants in their morphology. The standardized medium obtained established here can serve as an efficient method for the rapid propagation and the basic for further studies.

\section{ACKNOWLEDGMENT}

I would like to thank to Grant from Directorate General Higher Education (DIKTI) Kemendiknas of Republic Indonesia for supported my research.

\section{REFERENCES}

[1] Detres, C. Saer, N and Bernard, D. In Vitro Regeneration of The Tropical Multipurpose leguminous Tree Sesbania grandiflora from Cotyledon ekpans. Plant Cell Report. Volume 14. Numbers 2-3, 87 93, DOI : 10.1007/BF00233767.2007.

[2] Hussain. T. M, Thummala $\mathrm{C}$ and Ghanta RG. High frequency shoot regeneration of Stercula urens Roxb.An endangered tree species through cotyledonary node cultures. Afr. J. Biotechnol. 6(15): 16431649. 2007.

[3] Jones, R.. M dan Mannetje. Plant Resources of South-East Asia Forages. Procea. Hal 196 - 198. Bogor Indonesia.1992.

[4] Murashige, T. Plant Propagation by Tissue Culture. Ann. Rev. Plant Physiol. 25: 135 - 166.1974

[5] (NAS) National Academy of Sciences. Forages. Washington, DC.1979.

[6] Oger, P. Petit, A and Dessaux, YA . A simple technique for direct transformation and regeneration of diploid legume species Lotus japanicus. Plant Sci. 116:159-168.1996.

[7] Pazz, MM., Shou H, Guo Z, Zhang Z,a Banerjee AK and Wang K Assessment of conditions affecting Agrobacterium-mediated soybean transformation using the cotyledonary node explants.Euphytica 136: 167-179.2004.

[8] Prakash SN, Pental D and Bhalla-Sarin N . Regeneration of pieonpea ( (Cajanus cajan) from cotyledonary node via multiple shoot formation. Plant cell Rep. 13: 623-627.1994.

[9] Saini. R. Jaiwal, S and Jaiwal PK . Stable genetic transformation of Vigna mungo L. Hepper via Agrobacterium tumefaciens. Plant Cell Rep. 21:851-85.2003.

[10] Shaik, N. M, Manish, A, Nookaraju, A. Sushin, K. Sameer and Srivastaga. Improved method of in vitro regeneration in Leucaena leucocephala-a leguminous pulpwood tree species. Ind. J. Biol.-Plant 15: 312-318.2009.

[11] Suliansyah, I. Plant Tissue Culture. Yogyakata.leuticaprio.2013.

[12] Xie, D.Y and Hong Y. Agrobacterium-mediated genetic transformation of Acacia mangium. Plant Cell Rep. 20: 917922.2002. 